\title{
A CROSS SECTIONAL STUDY REGARDING HCV PATIENTS' KNOWLEDGE ABOUT VIRAL TRANSMISSION AND ATTITUDES REGARDING TOOTHBRUSH CARE
}

\author{
ESTUDO TRANSVERSAL SOBRE O CONHECIMENTO DA TRANSMISSÃO VIRAL E \\ AS ATITUDES EM RELAÇÃO AOS CUIDADOS COM AS ESCOVAS DENTÁRIAS \\ ENTRE PACIENTES INFECTADOS COM O HCV
}

\section{Cléa Adas Saliba GARBIN'; Neila Paula de SOUZA $^{2}$; Suzely Adas Saliba MOIMAZ³; Artênio José Ísper GARBIN ${ }^{4}$, Livia Melo VILLAR ${ }^{5}$}

1. Full Professor, Preventive and Social Dentistry Post-graduation Program, Universidade Estadual Paulista - Unesp, Araçatuba, SP, Brazil; 2. PhD, Preventive and Social Dentistry Post-graduation Program, Universidade Estadual Paulista - Unesp, Araçatuba, SP, Brazil. neilapsouza@ hotmail.com; 3. Full Professor and vice-coordinator, Preventive and Social Dentistry Post-graduation Program, Universidade Estadual Paulista - Unesp, Araçatuba, SP, Brazil; 4. Adjunct Professor, Preventive and Social Dentistry Post-graduation Program, Univ. Estadual Paulista - Unesp, Araçatuba, SP, Brazil; 5. Technologist, Viral Hepatitis Laboratory, Oswaldo Cruz Institute FIOCRUZ, Rio de Janeiro, RJ, Brazil;

\begin{abstract}
Hepatitis C virus (HCV) is transmitted mainly by parenteral route, although, some studies have pointed the potential of transmission by sharing infected instruments, like toothbrushes. The aim of this study was to investigate the knowledge about viral transmission among HCV infected individuals and attitudes regarding toothbrush care. A cross-sectional study was conducted among $112 \mathrm{HCV}$-infected individuals from Uberlandia City, Minas Gerais State (Southeast Brazil). Data were collected through a questionnaire containing demographic data and other questions (correct responses were given one point, incorrect and uncertain responses were given zero point) about knowledge of $\mathrm{HCV}$ transmission (6 items in total; scores lower than 4 points indicated poor knowledge level and scores equal or higher than 4 indicated good knowledge level); attitudes regarding toothbrush care ( 7 items; scores 0 to 3 indicated inadequate attitudes, and scores higher than 3 indicated adequate attitudes). The statistical analysis included Chi-square test, Exact Fisher's test and Maximum Likelihood Estimation ( $\mathrm{p}<0.05$ was considered significant). Out of the 112 questionnaires distributed, 85 (response rate: $75.9 \%$ ) were included. Most individuals were male (60\%), Caucasian (69.4\%), aged more than 51 years $(51.7 \%)$, had attended pre-school $(35.1 \%)$, and had incomes up to $\$ 525.2$ per month (49.4\%). Fifty four percent of individuals showed good Knowledge level of HCV transmission; $43.5 \%$ did not identify HCV transmission through toothbrushes and $80 \%$ did not believe in HCV transmission by saliva. A significant association were observed between Knowledge level of HCV and age $(p=0.020)$; and education level $(p=0.000)$. Forty-five HCV-infected individuals $(64.70 \%)$ had adequate attitudes regarding toothbrushes care. Significant associations were observed between toothbrush care level and: age $(\mathrm{p}=0.005)$; education level $(\mathrm{p}=0.000)$; and family income $(\mathrm{p}=0.038)$. HCV-infected individuals showed good knowledge level about main aspects of $\mathrm{HCV}$ infection and adequate attitudes regarding toothbrush care.
\end{abstract}

KEYWORDS: Hepatitis C virus. Knowledge. Saliva. Toothbrushing. Transmission.

\section{INTRODUCTION}

Hepatitis C virus (HCV) infection is a serious public health problem and the main cause of chronic hepatic disease, cirrhosis, hepatocarcinoma, and liver transplant (LINGALA; GHANY, 2015). The chronic disease is associated with impairments in health-related quality of life (SOUZA et al., 2015). Worldwide, 130-150 million individuals are chronically infected with HCV (WORLD HEALTH ORGANIZATION, 2015). In Brazil, HCV prevalence is $1.38 \%$ among individuals living in all geographical regions and among certain groups, such as beauticians and military personnel is less than 1\% (PEREIRA et al., 2013; VILLAR et al., 2014; VILLAR et al., 2015).
$\mathrm{HCV}$ is transmitted by exposure to contaminated fluids through blood transfusion, organ transplants, use of injectable drugs, unsafe intercourse with an HCV-infected individual, administration of unsafe therapeutic injections, and occupational exposure to contaminated blood (ALTER, 2011). Non-parenteral methods of HCV transmission could be possible; for example, $\mathrm{HCV}$ RNA (Hepatitis C Virus - Ribonucleic Acid) and anti-HCV have been detected in saliva samples of patients with chronic HCV infection (CRUZ et al., 2012; SOSA-JURADO et al., 2014), and HCV RNA has been detected among toothbrushes used by $\mathrm{HCV}$-infected individuals, suggesting at least a risk of infection from sharing these objects (LOCK et al., 2006). 
Because no $\mathrm{HCV}$ vaccine exists, prevention is the only safe approach to reduce $\mathrm{HCV}$ transmission. Many patients experience prejudice and discrimination from friends, family members, and health care providers (BRENER et al., 2015). Moreover, these patients fear transmitting the virus to family members (SGORBINI; O'BRIEN; JACKSON, 2009). Increasing individuals' knowledge of modes of $\mathrm{HCV}$ transmission and changing their attitudes toward HCV infection could help to prevent the spread of HCV.

Some studies have demonstrated different levels of knowledge of HCV infection among drugs users (SGORBINI; O'BRIEN; JACKSON, 2009; TRELOAR et al., 2013), homosexual men (DELVAUX et al., 2013; LAMBERS et al. 2014), and health professionals (BIANCO et al., 2013). Most individuals did not recognize the major modes of HCV transmission (CRUTZENA; GÖRITZ, 2012; SALEH et al., 2014); approximately $10 \%$ of HCV-infected individuals could not identify a risk factor for acquiring HCV (ALTER, 2002).

Few studies about HCV knowledge have been conducted among patients with chronic $\mathrm{HCV}$ infection (MARCHESINI et al., 2007; SHAH; ABU-AMARA, 2013; WU et al., 2015). Therefore, to the best of our knowledge, the aim of this study was to evaluated the knowledge about viral transmission among $\mathrm{HCV}$ infected individuals and attitudes regarding toothbrush care.

\section{MATERIAL AND METHODS}

\section{Study design and setting}

This cross-sectional study was conducted among HCV infected individuals from Uberlandia City, Minas Gerais State (Southeast Brazil). Subjects were recruited at Ambulatory of Chronic Liver Pathologies of Clinics Hospital of University of Uberlândia, Minas Gerais State. This institution is a reference center for liver disease diagnosis in Minas Gerais State and receives about 190 HCVinfected individuals per year.

\section{Study sample}

Sample size was calculated according to a probabilistic model considering finite population and a confidence level of $10 \%$ (FONSECA; MARTINS, 2001). ${ }^{24}$ The estimated number for the sample was $112 \mathrm{HCV}$-infected patients.

Subjects were recruited from February to December 2016. Inclusion criteria were: age 18 years and/or older; not present physical, mental or cognitive disturbance; had chronic HCV infection defined by the presence of anti-HCV and HCV
RNA in sera samples for more than 6 months, and formal consent to participate in the study.

Exclusion criteria were not being infected with hepatitis B virus (HBV) or human immunodeficiency virus (HIV), or have other concomitant liver diseases.

All individuals were selected after the analysis of medical records of patients with scheduled consultations at the hospital in the same period of data collection. On the scheduled date for consultation, all individuals were invited to participate; those who agreed to participate were interviewed individually in a confidential setting.

A pilot study to verify the applicability of these instruments was first conducted on 11 individuals with the same population characteristics. These patients were not included in the final sample.

\section{Ethical aspects}

The study was performed in accordance with the World Medical Association Declaration of Helsinki and was approved by the Ethical Committee in Human Research of Araçatuba Dental School. Respondents provided written consent before the research was initiated.

\section{Questionnaire}

Authors developed the questionnaire following a review of the literature on $\mathrm{HCV}$ aspects (ZEREMSKI et al., 2015) and pre-standardized it based on a sample of patients with chronic HCV infection. The questionnaire was divided into three topics: 1) demographic characteristics (i.e., age, gender, ethnicity, education level, occupation, civil status, and family income), 2) knowledge of HCV transmission, and 3) attitudes regarding toothbrush care.

Correct responses were given one point, incorrect and uncertain responses were given zero point. The section regarding $\mathrm{HCV}$ knowledge consisted of 6 items in two formats: 4 yes/no questions and 2 multiple choice questions requiring one or more answer. Scores lower than 4 points indicated poor knowledge level and scores equal or higher than 4 indicated good knowledge level.

The section about attitudes regarding toothbrush care consisted of consisted of 7 questions in two formats: 4 yes/no questions and 3 multiple choice questions requiring one answer. Adequate attitudes were given one point, and inadequates were given zero point. Scores 0 to 3 indicated inadequate attitudes, and scores higher than 4 indicated adequate attitudes.

At the end of the interview, the participants of the study were informed about correct answers. 


\section{Statistical analysis}

Data were analyzed using SPSS version 16 (IBM Inc., USA), yielding descriptive statistics (i.e., mean, frequency) and comparison means (i.e., oneway $\chi^{2}$ test, Exact Fisher's test). A p-value less than 0.05 was considered statistically significant.
GARBIN, C. A. S. et al.

\section{RESULTS}

\section{Social and demographics characteristics}

Out of the 112 individuals invited to participate of this study, 85 (response rate: $75.9 \%$ ) agreed. Most individuals were male $(\mathrm{n}=51 ; 60 \%)$, Caucasian $(\mathrm{n}=59 ; 69.4 \%)$, married $(\mathrm{n}=49 ; 57.6 \%)$, and older than 51 years $(n=44 ; 51.7 \%)$. They had a family income up to US\$525.2 per month $(\mathrm{n}=42$; $49.4 \%)$ and had pre-school $(\mathrm{n}=56 ; 35.1 \%)$ (Table 1$)$.

Table 1. Bivariate analysis regarding knowledge level of HCV infection in the population studied.

\begin{tabular}{|c|c|c|c|c|c|c|c|c|c|c|c|c|c|c|c|}
\hline \multirow{4}{*}{ Characteristic } & \multicolumn{15}{|c|}{ Knowledge level of HCV infection } \\
\hline & \multicolumn{4}{|c|}{$\begin{array}{l}\text { Male Gender } \\
\quad(\mathrm{n}=24)\end{array}$} & \multirow{3}{*}{ p-value } & \multicolumn{4}{|c|}{$\begin{array}{l}\text { Female Gender } \\
\qquad(\mathrm{n}=22)\end{array}$} & \multirow{3}{*}{ p-value } & \multicolumn{4}{|c|}{$\begin{array}{l}\text { Study population } \\
(\mathrm{n}=85)\end{array}$} & \multirow{3}{*}{ p-value } \\
\hline & \multicolumn{2}{|c|}{ Good } & \multicolumn{2}{|c|}{ Poor } & & \multicolumn{2}{|c|}{ Good } & \multicolumn{2}{|c|}{ Poor } & & \multicolumn{2}{|c|}{ Good } & \multicolumn{2}{|c|}{ Poor } & \\
\hline & $\mathrm{n}$ & $\%$ & $\mathrm{n}$ & $\%$ & & $\mathrm{n}$ & $\%$ & $\mathrm{n}$ & $\%$ & & $\mathrm{n}$ & $\%$ & $\mathrm{n}$ & $\%$ & \\
\hline \multicolumn{16}{|l|}{ Age (years) } \\
\hline $18-40$ & 10 & 41.7 & 4 & 14.8 & \multirow{4}{*}{$0.018 * *$} & 5 & 22.7 & - & - & \multirow{4}{*}{$0.147 * *$} & 15 & 32.6 & 4 & 10.3 & \multirow{4}{*}{0.020} \\
\hline $41-50$ & 3 & 12.5 & 9 & 33.3 & & 5 & 22.7 & 5 & 41.7 & & 8 & 17.4 & 14 & 35.9 & \\
\hline $51-60$ & 9 & 37.5 & 6 & 22.2 & & 6 & 27.3 & 3 & 25 & & 15 & 32.6 & 9 & 23.1 & \\
\hline$\geq 60$ & 2 & 8.3 & 8 & 29.6 & & 6 & 27.3 & 4 & 33.3 & & 8 & 17.4 & 12 & 30.8 & \\
\hline \multicolumn{16}{|l|}{$\bar{M}$ Marital status } \\
\hline Married & 16 & 66.7 & 20 & 74.1 & \multirow{4}{*}{$0.894 * *$} & 9 & 40.9 & 4 & 33.3 & \multirow{4}{*}{$0.287 * *$} & 25 & 54.3 & 24 & 61.5 & \multirow{4}{*}{$0.321 * *$} \\
\hline Single & 5 & 20.8 & 5 & 18.5 & & 7 & 31.8 & 4 & 33.3 & & 12 & 26.1 & 9 & 23.1 & \\
\hline Widowed & 2 & 8.3 & 1 & 3.7 & & 5 & 22.7 & 1 & 8.3 & & 7 & 15.2 & 2 & 5.1 & \\
\hline Divorced & 1 & 4.2 & 1 & 3.7 & & 1 & 4.5 & 3 & 25 & & 2 & 4.3 & 4 & 10.3 & \\
\hline \multicolumn{16}{|l|}{ Ethnicity } \\
\hline Caucasian & 19 & 79.2 & 18 & 66.7 & \multirow{2}{*}{0.318} & 16 & 72.7 & 6 & 50 & \multirow[t]{2}{*}{$0.265^{*}$} & 35 & 76.1 & 24 & 61.5 & \multirow{2}{*}{0.147} \\
\hline Non-Caucasian & 5 & 20.8 & 9 & 33.3 & & 6 & 27.3 & 6 & 50 & & 11 & 23.9 & 15 & 38.5 & \\
\hline \multicolumn{16}{|l|}{ Education level } \\
\hline Pre-school & 2 & 8.3 & 15 & 55.6 & \multirow{4}{*}{$0.000 * *$} & 7 & 31.8 & 2 & 16.7 & & 9 & 19.6 & 17 & 43.6 & \\
\hline Primary school & 5 & 20.8 & 6 & 22.2 & & 2 & 9.1 & 9 & 75 & $0.001 * *$ & 7 & 15.2 & 15 & 38.5 & $\cap \cap \cap \cap * *$ \\
\hline Secondary school & 12 & 50 & 6 & 22.2 & & 11 & 50 & 1 & 8.3 & & 23 & 50 & 7 & 17.9 & 0.000 \\
\hline College & 5 & 20.8 & - & - & & 2 & 9.1 & - & - & & 7 & 15.2 & - & - & \\
\hline $\begin{array}{l}\text { Family income (per } \\
\text { month) }\end{array}$ & & & & & & & & & & & & & & & \\
\hline$<$ US \$525.2 & 8 & 33.3 & 15 & 55.6 & & 12 & 54.5 & 7 & 58.3 & $0.895 * *$ & 20 & 43.5 & 22 & 56.4 & \\
\hline $\begin{array}{l}\text { US } \$ 525.2 \text { to US } \$ \\
787.8\end{array}$ & 11 & 45.8 & 6 & 22.2 & 0.171 & 7 & 31.8 & 4 & 33.3 & & 18 & 39.1 & 10 & 25.6 & 0.39 \\
\hline >US\$ 787.8 & 5 & 20.8 & 6 & 22.2 & & 3 & 13.6 & 1 & 8.3 & & 8 & 17.4 & 7 & 17.9 & \\
\hline
\end{tabular}

\section{HCV knowledge}

Only $23.5 \% \quad(\mathrm{n}=20) \quad$ of $\quad \mathrm{HCV}$-infected individuals knew the main modes of $\mathrm{HCV}$ transmission. The most cited modes were contaminated syringe $(\mathrm{n}=81,95.3 \%)$ and blood transfusion $(\mathrm{n}=60,70.6 \%)$.

Eight $(9.4 \%) \mathrm{HCV}$-infected individuals did not answer that bacteria, fungi, or viruses could be transmitted from the oral cavity to the toothbrush. Among individuals who believed that diseases caused by bacteria, fungus, or virus could be transmitted from the oral cavity to the toothbrush, only $15.3 \%(n=13)$ were able to mention the name of some diseases; the most commonly named diseases were herpes $(n=5)$, hepatitis $(n=3)$, and gingivitis $(\mathrm{n}=2)$.

Regarding the transmission of infectious agents (bacteria, fungus, or virus) from toothbrush to oral cavity, $5.9 \% \quad(n=5)$ of $\mathrm{HCV}$-infected individuals did not believe in this possible mode of $\mathrm{HCV}$ transmission. Additionally, 43.5\% $(n=37)$ of the individuals did not believe that $\mathrm{HCV}$ could be transmitted through toothbrushes and 20\% $(n=17)$ believed in $\mathrm{HCV}$ transmission by saliva. 
Fifty-four percent $(\mathrm{n}=46)$ of $\mathrm{HCV}$-infected individuals showed good knowledge level of HCV. A significant association were observed between Knowledge level of $\mathrm{HCV}$ of males individuals and age $(\mathrm{p}=0.018)$; knowledge level all study population and age $(\mathrm{p}=0.020)$; Knowledge level of HCV and education level of males $(p=0.000)$, females $(\mathrm{p}=0.001)$ and all study population $(\mathrm{p}=$ 0.000) (Table 1).

No significant association were observed between knowledge level of $\mathrm{HCV}$ and toothbrush care level $(\mathrm{p}=0.309)$.

\section{Toothbrush care}

Table 2 shows data regarding attitudes concerning the use of toothbrushes. All study participants reported that they washed their toothbrushes under running water after use. Among
GARBIN, C. A. S. et al.

the HCV-infected individuals, $60 \%(\mathrm{n}=51)$ affirmed that after brushing their teeth, they washed the toothbrush under running water before storing it; $25.9 \%(n=22)$ washed it and scrubbed the bristles with their fingers to eliminate excess water; and $7.1 \%(\mathrm{n}=6)$ washed it and hit it on the bathroom sink to remove excess water.

Forty-five HCV-infected individuals $(64.70 \%)$ had adequate attitudes regarding toothbrushes care. Significant associations were observed between toothbrush care level of male gender and age $(p=0.002)$; toothbrush care level of all study sample and age $(\mathrm{p}=0.005)$; toothbrush care level of male gender and education level $(p=0.002)$; toothbrush care level of all study sample and education level $(p=0.000)$; and toothbrush care level of all study sample and family income $(\mathrm{p}=$ $0.038)$.

Table 2. Attitudes regarding toothbrush care among HCV-infected individuals.

\begin{tabular}{|c|c|c|}
\hline \multirow[t]{2}{*}{ Variables } & \multicolumn{2}{|c|}{$\begin{array}{c}\text { HCV-infected } \\
\text { individuals } \\
(\mathrm{n}=85)\end{array}$} \\
\hline & $\mathrm{n}$ & $\%$ \\
\hline \multicolumn{3}{|l|}{ Toothbrushing frequency (per day) } \\
\hline Once & 5 & 5.9 \\
\hline Twice & 35 & 41.2 \\
\hline Three times & 30 & 35.3 \\
\hline More than three times & 15 & 17.7 \\
\hline \multicolumn{3}{|l|}{ Toothbrush sharing frequency } \\
\hline Once a month & 8 & 9.4 \\
\hline Once every 2 to 3 months & 38 & 44.7 \\
\hline Once every 3 to 4 months & 19 & 22.4 \\
\hline Once every 4 to 5 months & 6 & 7.1 \\
\hline Once every 6 months to 1 year & 13 & 15.3 \\
\hline Once a year & 1 & 1.2 \\
\hline \multicolumn{3}{|l|}{ Toothbrush sharing } \\
\hline No & 70 & 82.4 \\
\hline Yes & 15 & 17.7 \\
\hline \multicolumn{3}{|c|}{ Use of antiseptic solution for washing toothbrush } \\
\hline No & 81 & 95.3 \\
\hline Yes & 4 & 4.7 \\
\hline \multicolumn{3}{|l|}{ Type of storage of toothbrush } \\
\hline Bathroom shelf & 36 & 42.4 \\
\hline Horizontally on bathroom sink & 2 & 2.4 \\
\hline Inside a holder on bathroom sink & 36 & 42.4 \\
\hline Other local & 11 & 12.9 \\
\hline \multicolumn{3}{|l|}{ Use of toothbrush holder } \\
\hline No & 43 & 50.6 \\
\hline Yes & 42 & 49.4 \\
\hline \multicolumn{3}{|l|}{ Type of toothbrush holder } \\
\hline Shared & 26 & 62 \\
\hline Single & 16 & 38 \\
\hline Uncovered & 23 & 55 \\
\hline Covered & 19 & 45 \\
\hline
\end{tabular}

$\mathrm{HCV}$, hepatitis $\mathrm{C}$ virus 


\section{DISCUSSION}

This study investigated knowledge about $\mathrm{HCV}$ transmission and attitudes regarding toothbrush care among HCV-infected individuals. Most individuals demonstrated good knowledge about $\mathrm{HCV}$. This finding may be explained by the fact that patients with HCV seek to acquire knowledge about the disease after being diagnosed. Previous research has also shown that patients from the United States and China have good knowledge of HCV (WU et al., 2015), however, permanent health education must be way to improve the knowledge level of patients and the population general about viral hepatitis (VILLAR et al., 2015).

Instruments containing HCV particles, like toothbrushes could be a potential method for viral transmission like previously reported (KOSAI; IWAI; MIURA, 1989; LOCK et al, 2006). Toothbrushes are essential to reduce biofilm and to maintain oral health (YAACOB et al., 2014); however, a theoretical risk of infection exists by sharing toothbrushes (LOCK et al., 2006). Although most HCV-infected individuals in this study believed in possible transmission of pathogens from the oral cavity to toothbrushes or vice versa, only a small percentage of respondents named a disease that they believed could be transmitted.

Only 20\% $(\mathrm{n}=17)$ of individuals reported that HCV could be transmitted by saliva. Although HCV RNA has been detected in the saliva of patients infected with HCV (SOSA-JURADO et al., 2014), the transmission of virus by this fluid were not well established. However the presence of injuries in oral cavity associated to absence of biosafety practices during dental treatment could be a risk factor for $\mathrm{HCV}$ transmission due to the presence of contaminated blood during dental procedures (GARBIN et al., 2014).

The American Dental Association recommends that consumers brush their teeth at least twice a day; replace toothbrushes every 3-4 months or sooner if the bristles become frayed with use; not share toothbrushes to avoid exchanging body fluids or microorganisms between users; remove excess paste and debris by rinsing the toothbrush under water after use; store toothbrushes upright if possible and let them air dry; and not routinely cover toothbrushes or store them in closed containers (AMERICAN DENTAL ASSOCIATION, 2005).

In the study, most individuals showed adequate attitudes regarding toothbrush care and reported that they replaced toothbrushes in the correct frequency (every 3-4 months). This period is recommended for toothbrushes replacement, since longer period of use contributes to the proliferation of microorganisms (AMERICAN DENTAL ASSOCIATION, 2005).

The majority of HCV-infected individuals did not use antiseptic solutions, which could be attributed either to lack of knowledge of the importance of disinfecting toothbrushes after use or to the high cost of such solutions. Antiseptic solutions could provide an effective way to reduce $\mathrm{HCV}$ infection rates and minimize the risk of crossinfection through toothbrushes (AMERICAN DENTAL ASSOCIATION, 2005). Ciesek et al showed that glutaraldehyde at $0.5 \%$ and peracteic acid at $0.05 \%$ were able to completely inactivate $\mathrm{HCV}$ within a 1-min incubation time (CIESEK et al., 2010).

In situations where an individual has a systemic disease that may be transmissible by blood or saliva, the American Dental Association recommends rinsing toothbrushes with an antibacterial mouthrinse before brushing to prevent or decrease bacterial growth; additionally, soaking them in an antibacterial mouthrinse after use may decrease bacterial growth (AMERICAN DENTAL ASSOCIATION, 2005).

Regarding the resistance of $\mathrm{HCV}$, culture of cells originating from $\mathrm{HCV}(\mathrm{HCVcc})$ can remain infectious for up to 6 weeks when stored at temperatures of $4^{\circ} \mathrm{C}$ and $22^{\circ} \mathrm{C}$, supporting the hypothesis of potential transmission from fomites. Thus, exposure to blood or body fluids contaminated with HCV, such as saliva, even after a long period, is a risk factor for $\mathrm{HCV}$ infection (AMERICAN DENTAL ASSOCIATION, 2005). To help prevent HCV transmission, individuals should correctly clean, disinfect, and store toothbrushes and not share them.

Most individuals stored toothbrushes inadequately in bathroom cabinets, atop bathroom sinks, or inside toothbrush holders, which were often shared, increasing the risk of cross-infection (GARBIN et al., 2014). The conditions for storing toothbrushes play an important role in the survival of pathogens (FRAZELLE; MUNRO, 2012).

This study has some limitations: the inclusion of outpatients from one single center; and the and the response rate.

\section{CONCLUSIONS}

Most $\mathrm{HCV}$-infected individuals showed good knowledge level of $\mathrm{HCV}$ and believed that there was a risk of infection through toothbrushes, 
although the minority believed that HCV could be transmitted through the saliva.

Most of individuals showed adequate attitudes regarding toothbrush care; however, it is important to emphasize that the majority of individuals did not use did not use antiseptic solutions in order to minimize the risk of crossinfection through toothbrushes.

\section{ACKNOWLEDGEMENTS}

The authors would like to thank the Coordination of the Improvement of Higher Education Personnel (CAPES).

RESUMO: O vírus da hepatite $\mathrm{C}(\mathrm{HCV})$ é transmitido principalmente por via parenteral, entretanto, estudos têm apontado o potencial de transmissão do HCV por vias não parentais, tal como por meio do compartilhamento de objetos contaminados, como as escovas dentárias. O objetivo deste estudo foi investigar o conhecimento sobre a transmissão viral e as atitudes em relação aos cuidados com as escovas dentárias entre indivíduos infectados com HCV. Trata-se de um estudo transversal realizado com 112 indivíduos, em Uberlândia, Minas Gerais (região sudeste do Brasil). Os dados foram coletados através de um inquérito contendo questões sobre os dados demográficos e outras questões (respostas corretas receberam um ponto, respostas incorretas e incertas receberam zero ponto) sobre o conhecimento da transmissão do HCV (6 itens no total; pontuações inferiores a 4 indicaram um nível de conhecimento pobre e pontuações igual ou superior a 4 indicaram um bom nível de conhecimento); atitudes em relação ao cuidado com as escovas dentárias ( 7 itens; pontuações de 0 a 3 indicaram atitudes inadequadas e superiores a 3 indicaram atitudes adequadas). A análise estatística incluiu os testes: Qui-quadrado, exato de Fisher e estimação de máxima verossimilhança ( $p<0,05$ foi considerado significativo). Dos 112 questionários distribuídos, 85 foram incluídos (taxa de resposta: 75,9\%). A maioria dos indivíduos era do sexo masculino (60\%), com idade acima de 51 anos $(51,7 \%)$, havia concluído apenas a pré-escola $(35,1 \%)$ e tinha renda de US\$ 525,2 por mês $(49,4 \%)$. Entre os pacientes, $54 \%$ apresentaram um bom nível de conhecimento sobre a transmissão do $\mathrm{HCV}$; 43,5\% não acreditavam na transmissão do vírus por meio das escovas dentárias e $80 \%$ não acreditaram na transmissão do HCV pela saliva. Verificou-se associação significativa entre o nível de conhecimento sobre o HCV e: idade $(p=0,020)$; nível de escolaridade $(p=0,000)$. Quarenta e cinco indivíduos $(64,70 \%)$ apresentaram atitudes adequadas em relação aos cuidados com escovas dentárias. Foram observadas associações significativas entre o nível de cuidado em relação às escovas e: idade $(\mathrm{p}=0,005)$; nível de escolaridade $(\mathrm{p}=$ $0,000)$; renda familiar $(\mathrm{p}=0,038)$. Os indivíduos infectados pelo HCV mostraram um bom nível de conhecimento sobre os principais aspectos da infecção pelo vírus e atitudes adequadas em relação aos cuidados com as escovas dentárias.

PALAVRAS-CHAVE: Hepacivírus. Conhecimento. Saliva. Escovação Dentária. Transmissão.

\section{REFERENCES}

Alter, M. J. HCV routes of transmission: what goes around comes around. Semin Liver Dis, New York, v. 31, n. 4, 2011. https://doi.org/10.1055/s-0031-1297923

Alter, M. J. Prevention of spread of hepatitis C. Hepatology. Baltimore, v. 36, n. 5, S93-8, nov.2002. https://doi.org/10.1053/jhep.2002.36389

AMERICAN DENTAL ASSOCIATION. Statement on toothbrush care: cleaning, storage, and replacement. 2005. http://www.ada.org/1887aspx. Accessed March 12, 2016.

BIANCO, A.; BOVA, F.; NOBILE, C. G. A.; PILLEGI, C.; PAVIA, M. Healthcare workers and prevention of hepatitis $\mathrm{C}$ virus transmission: exploring knowledge, attitudes and evidence-based practices in hemodialysis units in Italy. BMC Infect Dis, London, v. 13, n. 76, 2013. https://doi.org/10.1186/1471-2334-13-76

BRENER, L.; HORWITZ, R.; VON HIPPEL, C.; BRYANT, J.; TRELOAR, C. Discrimination by health care workers versus discrimination by others: countervailing forces on HCV treatment intentions. Psychol Health Med, Abingdon, v. 20, n. 2, p. 148-53, jun. 2014. https://doi.org/10.1080/13548506.2014.923103

CIESEK, S.; FRIESLAND, M.; STEINMANN, J.; BECKER, B.; WEDEMEYER, H.; MANNS, M. P.; STEINMANN, J.; PIETSCHMANN, T.; STEINMANN, E. How stable is the hepatitis C virus (HCV)? 
Environmental stability of HCV and its susceptibility to chemical biocides. J Infect Dis, Chicago, v. 201, n. 12, p. 1859-66, jun. 2010. https://doi.org/10.1086/652803

CRUTZENA, R.; GÖRITZ, A. S. Public awareness and practical knowledge regarding Hepatitis A, B, and C: a two-country survey. J Infect Public Health, Oxford, v. 5, n. 2, p. 195-8, apr. 2012. http://dx.doi.org/10.1016/j.jiph.2011.12.001

CRUZ, H. M.; MARQUES, V. A.; VILLELA-NOGUEIRA, C. A.; Ó, K. M.; LEWIS-XIMENEZ, L. L.; LAMPE, E.; VILLAR, L. M. An evaluation of different saliva collection methods for detection of antibodies against hepatitis C virus (anti-HCV). J Oral Pathol Med, Oxford, v. 41, n. 10, p. 793-800, jun.2012. http://dx.doi.org/ 10.1111/j.1600-0714.2012.01176.x

DELVAUX, N.; PAULA, V. S.; ESPIRITO-SANTO, M. P.; SILVA, E. F.; MIGUEL, J. C.; OLIVEIRA, J. C.; SILVA, A.S.; VIEIRA, Y. R.; LAMPE, E.; VILLAR, L. M. Knowledge about viral hepatitis among participants of Gay Pride Event in Brazil. Braz J Infect Dis, Rio de Janeiro, v. 17, n. 3, p. 377-8, mayjun.2013. http://dx.doi.org/10.1016/j.bjid.2012.09.015

FONSECA, J. S.; MARTINS, G. A. Curso de estatística. 6th ed. São Paulo: Atlas; 2001. 320p.

FRAZELLE, M. R.; MUNRO, C. L. Toothbrush contamination: a review of the literature. Nurs Res Pract, Cairo, v. 2012, n. 2012, 420630, 6 p. 2012. http://dx.doi.org/10.1155/2012/420630.

GARBIN, C. A.; DE SOUZA, N. P.; DE VASCONCELOS, R. R.; GARBIN, A. J.; VILLAR, L. M. Hepatitis $\mathrm{C}$ virus and dental health workers: an update. Oral Health Prev Dent, New Malden, v. 12, n. 4, p. 313-21, dec. 2014. http://dx.doi.org/10.3290/j.ohpd.a32134.

KOSAI, K.; IWAI, T.; MIURA, K. Residual contamination of toothbrushes by microorganisms. ASDC J Dent Child, Chicago, v. 56, n. 3, p. 201-4, may-jun.1989. PMID: 2723207

LAMBERS, F. A. E.; PRINS, M.; DAVIDOVICH, U.; STOLTE, I. G. High awareness of hepatitis C virus (HCV) but limited knowledge of HCV complications among HIV-positive and HIV-negative men who have sex with men. AIDS Care, London, v. 26, n. 4, p. 416-24, set. 2014. http://dx.doi.org/10.1080/09540121.2013.832721.

LINGALA, S.; GHANY, M. G. Natural history of hepatitis C. Gastroenterol Clin North Am, Philadelphia, v. 44, n. 4, p. 717-34, dec. 2015. http://dx.doi.org/10.1016/j.gtc.2015.07.003.

LOCK, G.; DIRSCHERL, M.; OBERMEIER, F.; GELBMANN, C. M.; HELLERBRAND, C.; KNÖLL, A.; SCHÖLMERICH, J.; JILG, W. Hepatitis C - contamination of toothbrushes: myth or reality? J Viral Hepat, Oxford, v. 13, n. 9, p. 571-3, sep. 2006. http://dx.doi.org/ 10.1111/j.1365-2893.2006.00735.x

MARCHESINI, A. M.; PRÁ-BALDI, Z. P.; MESQUITA, F.; BUENO, R.; BUCHALLA, C. M. Hepatitis B and $C$ among injecting drug users living with HIV in São Paulo, Brazil. Rev Saúde Pública, São Paulo, v. 41(Suppl 2), p. 4157-63, feb.2007. http://dx.doi.org/10.1590/S0034-89102007000900010

PEREIRA, L. M.; MARTELLI, C. M.; MOREIRA, R. C.; MERCHAN-HAMMAN, E.; STEIN, A. T.; CARDOSO, R. M. A.; FIGUEIREDO, G. M.; MONTARROYOS, U. R.; BRAGA, C.; TURCHI, M. D.; CORAL, G.; CRESPO, D.; LIMA, M. L. C.; ALENCAR, L. C. A.; COSTA, M., SANTOS, A. A.; XIMENES, R. A. A. Prevalence and risk factors of Hepatitis C virus infection in Brazil, 2005 through 2009: a crosssectional study. BMC Infect Dis, London, v. 13, n. 60, feb. 2013. http://dx.doi.org/10.1186/1471-2334-13-60.

SALEH, D. A.; AMR, S.; JILLSON, I. A.; WANG, J. H.; KHAIRY, W. A.; LOFFREDO, C. A. Knowledge and perceptions of hepatitis $\mathrm{C}$ infection and pesticides use in two rural villages in Egypt. BMC Public Health, London, v. 14, n. 501, may. 2014. http://dx.doi.org/10.1186/1471-2458-14-501 
SGORBINI, M.; O'BRIEN, L.; JACKSON, D. Living with hepatitis C and treatment: the personal experiences of patients. J Clin Nurs, Oxford, v. 18, n. 16, p. 2282-91, aug. 2009. http://dx.doi.org/10.1111/j.13652702.2009.02806.x

SHAH, H. A.; ABU-AMARA, M. Education provides significant benefits to patients with hepatitis B virus or hepatitis $C$ virus infection: a systematic review. Clin Gastroenterol Hepatol, Philadelphia, v. 11, n. 8, p. 92233, aug. 2013. http://dx.doi.org/10.1016/j.cgh.2013.04.024.

SOSA-JURADO, F.; HERNÁNDEZ-GALINDO, V. L.; MELÉNDEZ-MENA, D.; MENDOZA-TORRES, M. A.; MARTÍNEZ-ARRONIZ, F. J.; VALLEJO-RUIZ, V.; REYES-LEYVA, J.; SANTOS-LÓPEZ, G. Detection of hepatitis C virus RNA in saliva of patients with active infection not associated with periodontal or liver disease severity. BMC Infect Dis, Rio de Janeiro, v. 14, n. 72, feb. 2014. http://dx.doi.org/10.1186/1471-233414-72.

SOUZA, N. P.; VILLAR, L. M; GARBIN, A. J. Í; ROVIDA, T. A. S.; GARBIN, C. A. S. Assessment of health-related quality of life and related factors in patients with chronic liver disease. Braz J Infect Dis, Rio de Janeiro, v. 19, n. 6, sep. 2015. http://dx.doi.org/10.1016/j.bjid.2015.08.003

TRELOAR, C.; HULL, P.; BRYANT, J.; HOPWOOD, M.; GREBELY, J.; LAVIS, Y. Factors associated with hepatitis $\mathrm{C}$ knowledge among a sample of treatment naive people who inject drugs. Drug Alcohol Depend, Limerick, v. 116, n. 1-3, p. 52-6, jul. 2011. http://dx.doi.org/10.1016/j.drugalcdep.2010.11.018.

VILLAR, L. M.; SOUZA, N. P.; MOIMAZ; S. A. S.; GARBIN, A. J. I.; BORGES, A. S.; GARBIN, C. A. S. Epidemiological profile of hepatitis $C$ virus infection in patients from west region of Minas Gerais State, Brazil. Biosci. J., Uberlândia, v. 31, n. 2, p. 643-647, mar-apr. 2015. http://dx.doi.org/10.14393/BJv31n2a2015-26538

VILLAR, L. M.; DE PAULA, V. S.; DE ALMEIDA, A. J.; DO Ó, K. M.; MIGUEL, J. C.; LAMPE, E. Knowledge and prevalence of viral hepatitis among beauticians. J Med Virol, New York, v. 86, n. 9, p. 151521, sep. 2014. http://dx.doi.org/ 10.1002/jmv.23993

VILLAR, L. M.; Ó KM, SCALIONI, L. P.; CRUZ, H. M.; PORTILHO, M. M.; MENDONÇA, A. C.; MIGUEL, J. C.; FIGUEIREDO, A. S.; ALMEIDA, A. J.; LAMPE, E. Prevalence of hepatitis B and C virus infections among military personnel. Braz J Infect Dis, Rio de Janeiro, v. 19, n. 3, p. 285-90, may-jun. 2015. http://dx.doi.org/10.1016/j.bjid.2015.02.002.

WORLD HEALTH ORGANIZATION. Hepatitis C. Fact sheet $N^{\circ} 164.2015$

http://www.who.int/mediacentre/factsheets/fs164. Accessed March 12, 2016.

WU, E; CHEN, X.; GUAN, Z.; CAO, C.; RAO, H.; FENG, B.; CHAN, M.; FU, S; LIN, A.; WEI, L.; LOK, A. S. A comparative study of patients' knowledge about hepatitis $C$ in the United States and in urban and rural China. Hepatol Int. New York, v. 9, n. 1, p. 58-66, jul. 2015. http://dx.doi.org/10.1007/s12072-014-9559-z.

YAACOB, M.; WORTHINGTON, H. V.; DEACON, S. A.; DEERY, C.; WALMSLEY, A. D.; ROBINSON, P. G.; GLENNY, A. M. Powered versus manual toothbrushing for oral health. Cochrane Database Syst Rev, Chichester, v. 17, n. 6, CD002281, jun. 2014. http://dx.doi.org/10.1002/14651858.CD002281.pub3.

ZEREMSKI, M.; DIMOVA, R. B.; ZAVALA, R.; KRITZ, S.; LIN, M.; SMITH, B. D.; ZIBBELL, J. E.; TALAL, A. H. Hepatitis C virus-related knowledge and willingness to receive treatment among patients on methadone maintenance. J Addict Med, Hagerstown, v. 8, n. 4, p. 249-57, jul-aug.2014. http://dx.doi.org/ 10.1097/ADM.0000000000000041 